\title{
Austen Goes to Norway
}

Jane Austen's early travels took her in several directions: to three central European countries, Switzerland, France, and Germany, to one southern European country, Portugal, and in the North to Sweden, Denmark and Norway. Norway was thus the seventh country and Norwegian was the sixth language to receive her. This nineteenth-century translation, however, has been unknown and unregistered until very recently.

Twentieth- and twenty-first-century reception has produced eight more translations in book form, and two versions for a magazine. ${ }^{1}$ At the outset, there are two remarkable things about them: they do not include Northanger Abbey, which has never been translated into Norwegian. While on the other hand, Pride and Prejudice has been translated no less than five times, and Persuasion twice. Nothing of the juvenilia (for example Lady Susan) or letters has appeared in Norwegian, and there has never been a proper collected edition.

The Norwegian reception is therefore, as in the rest of Scandinavia, a little paradoxical. It took almost sixty years before the second translation appeared (1930), and she did not receive proper attention from publishers and translators until the last years of the century. Yet, Norwegians were among the very first in the world to receive her, in an 1871 translation. Moreover, Norwegian reception is earlier and more comprehensive than Norwegian translations, since Danish translations also served the Norwegian market. Thus, Jane Austen was read in translation at least as early as 1856 , when E.J. Engelsens Leiebibliothek (rental library) acquired a copy of the Danish 1855 translation of Sense and Sensibility. ${ }^{2}$ In addition, there are copies of Austen's novels in English in libraries and reading societies in the mid-century and later, to wit the $185^{2}$ catalogue of the male Athenceum society, which comprises Emma, Pride and Prejudice and Sense and Sensibility. ${ }^{3}$ Austen had therefore been present in a few catalogues and on some bookshelves for two decades before the first Norwegian translation appeared.

1 In addition, there is a 2007 textbook extract from Pride and Prejudice translated into the minority language New Norwegian.

2 List of acquisitions published in the newspaper Bergen Adressecontoirs Efterretninger, Bergen, 8 July, 1856.

3 Catalog over Athenceums Bøger, Oslo, 1852, 114.

(C) MARIE NEDREGOTTEN SøRBø, 2018 | DOI 10.1163/9789004337176_003

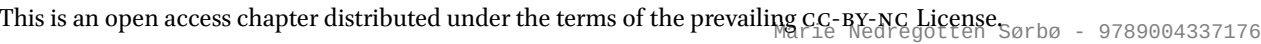




\section{The 1871 Translation}

The first of Jane Austen's novels to be translated into Norwegian was Persuasion in 1871 , although this translation has been invisible in the history of Austen reception. ${ }^{4}$ David Gilson did not find it when he travelled around, searching the libraries and archives of different countries for translations. He was for instance in Sweden, examining the 1836 translation, and he did include all the twentieth-century Norwegian translations that had appeared at the time.

He had no chance of finding it, because it was not recorded in library catalogues. For the same reason, I myself did not find it when doing research for the Norwegian chapter of The Reception of Jane Austen in Europe. ${ }^{5}$ It is only included in the second, updated edition. ${ }^{6}$ This is why it is not mentioned in Anthony Mandal's 2012 overview of the European reception. ${ }^{7}$ The first presentation of the 1871 translation was published in "Discovering an Unknown Austen" in 2013 (dated 2012). ${ }^{8}$

The absence of the translation from library catalogues indicates that it had never been published as a book. It was translated for a major, national newspaper, Morgenbladet ("The Morning Post"), and appeared in daily instalments from December 201871 to January $231872 .{ }^{9}$ A very common way of publishing novels in the latter half of the nineteenth century, the largest national and regional newspapers sectioned off the bottom of the page for the daily portion of the running serial. They were designed to be cut out so that readers could collect their own little library of current novels.

Librarian J.B. Halvorsen was a contemporary witness to the practice. In the preface to his 1885 encyclopaedia of authors he observes that newspapers and weekly magazines had increasingly taken over the role of transmitters of literature, especially in the preceding decades. ${ }^{10}$

4 Jane Austen, "Familien Elliot", Morgenbladet, 351B (1871) - 22 (1872), 1-2.

5 The Reception of Jane Austen in Europe, eds B.C. Southam and Anthony Mandal, London, 2007, 184 .

6 The Reception of Jane Austen in Europe, eds Mandal and Southam, 2014.

7 Anthony Mandal, "Austen's European Reception", in A Companion to Jane Austen, eds Claudia L. Johnson and Clara Tuite, Malden and Oxford, 2012, 422-33.

8 Marie Nedregotten Sørbø, "Discovering an Unknown Austen: Persuasion in the Nineteenth Century", Persuasions 34 (2012), 245-54.

9 This included Sunday editions, and even on the 24 and 25 of December (but not the 26th). Although there are around the same number of instalments as chapters in the novel (twenty-four), they do not correspond, but are decided by column format.

10 Jens Braage Halvorsen, Norsk forfatter-lexikon 1814-1880, A-B, Oslo, 1885, x. 
The practice has recently been described by Aina Nøding in a history of the Norwegian press, and she also mentions en passant that Austen's Persuasion was among the translated works. ${ }^{11}$ Coincidentally, she unearthed a piece of Austen reception that had been deeply buried in an unmarked grave, impossible to find unless reading through the relevant issues of the newspaper. The discovery may well indicate that other important items of reception will come to light in the future, in all countries, as historical sources are made more readily available for researchers.

Norwegian newspaper serials provided readers with the novels of, for instance, George Eliot and Charles Dickens, Elizabeth Gaskell and Margaret Oliphant. The difference between them and Jane Austen was that they were reissued in book-form straight after serial publication, and hence registered in libraries. The fact that Austen's novel was not, may be an indication that she was less highly regarded.

There seems to be little or no distinction between serious and entertainment literature. The newspaper editors had one main criterion: to get hold of the most popular novels and most talked of authors. This meant going for the newest novels on the market, and they sometimes translated a novel within the same year or the next (for instance, Ada Bayly's A Hardy Norseman in 1889). There are few exceptions to this rule of newness and topicality, but the translation of Frances Burney in 1858 and Jane Austen in 1871 are two such rare cases. Why were these two conceivably old and out-dated authors suddenly received in Norway, half a century after their own time? Burney seems to have had a champion who felt that she was too neglected, and who did the translation and wrote an article about her. ${ }^{12}$ Austen's case is a little different: there is no article presenting her, there is no information at all about the author except her name, there is only the text of the novel.

Austen's sudden appearance seems not to be due to the efforts of a particular champion, but rather to a certain topicality. The translation appeared just after James Edward Austen-Leigh had published his Memoir (1869), which was re-edited with more material exactly in $1871 .{ }^{13}$ Although this was not translated into Norwegian, it caused much attention around Jane Austen's name in England. Furthermore, Norwegian editors read English media, and often took

\footnotetext{
11 Aina Nøding, "Fra fabler til føljetonger", in Norsk Presses Historie (1660-2010): En samfunnsmakt blir til: 166o-1880, eds Martin Eide and Hans Fredrik Dahl, Oslo, 2010, I, 305-59.

12 Ludvig Daae (unsigned), "Frances Burney”, Illustreret Nyhedsblad, VII/49, 1858, 1; Frances Burney, Evelina: eller En ung Piges Intrcedelse i Verden, Oslo, 1858.

13 Now available in for instance A Memoir of Jane Austen by Her Nephew J.E. Austen-Leigh, eds R.W. Chapman and Fay Weldon, London, 1989.
} 
their material from English journals. It seems more than a coincidence that Jane Austen, who had been almost invisible in Norway, was suddenly found worthy of publication the same year that she was rediscovered in England.

An equally significant factor of timing is that the previous years had seen two new editions of her novels - the Bernhard Tauchnitz series published in English in Leipzig, and the Chapman and Hall editions published in London. Particularly noteworthy is the fact that Tauchnitz issued Persuasion in 1871, the very same year that the Norwegian newspaper serial started printing it. ${ }^{14}$ It is just conceivable that Morgenbladet had managed to have a translation based on this, ready for the first instalments in late December.

The translation is anonymous, which was then rather the rule than the exception, especially in newspapers. There are several possible candidates, people who are known to have been translating for this newspaper at the time, but the translator's identity remains unconfirmed. ${ }^{15}$

Alternatively, the translator could conceivably have been Danish, and the translation only modified for the Norwegian newspaper. The two countries still shared more or less the same language and the same book-market after four hundred years of union. However, no similar Danish Persuasion has so far surfaced.

The translator, whoever he or she was, was well qualified for the task. There is a better mastery of English that in some of the twentieth-century translations. He or she has a good grasp of idioms, a proper understanding of the story, characters and events, and often a meticulous rendering of the meaning of sentences.

The peculiar characteristic of this translation is elaboration. If it errs, it is in this direction, and not, as in several others, in deletion. Compared to George Eliot's Middlemarch, similarly translated for the press two years later in 1873, that was substantially (although cleverly) abbreviated. Austen's novel is not reduced, and not only because it is shorter than Eliot's to begin with. Some of Austen's twentieth-century translations are reduced versions. For Austen and Eliot in the 1870 , it is a matter of two translators with distinct styles of translation.

The Norwegian Persuasion has a different title than the original novel: Familien Elliot ("The Elliot Family"). At first glance, it seems to be merely another version of the Swedish Familjen Elliot (1836), which is a translation of Isabelle

\footnotetext{
14 See Gilson, A Bibliography of Jane Austen, 253.

15 One of them is Kristian Winterhjelm, who later translated Gulliver's Travels. The style of the Austen translation is somewhat similar to that of the equally anonymous translation of George Eliot's “The Lifted Veil” in 1878.
} 
de Montolieu's French version La Famille Elliot (1821) - in effect, a fourth-hand version of the novel. Luckily, it proves to be an independent translation, in spite of its appearances. ${ }^{16}$ It takes only a few checks to see the difference. Montolieu, who was an author in her own right and more famous than Austen at the time, edited the novel, and changed parts that did not fit in with her taste for sentimental stories. She changed the heroine's name from everyday Anne to the more romantic Alice, and she makes her pregnant on the last page, to make the family idyll complete. This does not happen in the Norwegian version, which follows Austen's original in almost all respects, with the conspicuous exception of the last chapter (see below, Chapter 10: Irony).

The 1871 translation seems soon to have been forgotten. No literary historian mentions it, ${ }^{17}$ and when the next Austen translation appears, its translator particularly recommends Persuasion as being Austen's art at its purest, without mentioning that it has been translated into Norwegian. ${ }^{18}$

It may be surprising to find that a small country in the corner of Europe was among the first receivers of Austen. However, it does reflect the Norwegian market for translated literature. The Norwegian openness to translations dates back to around 1000 A.D. and the need of the Christian church to make legends and religious texts available for the people. There are surviving translations from Latin dating back to around 1150, even before the Old Testament was translated in the next century. The first known piece of fiction to be translated into Norwegian (Old Norse) was Tristram og Isond, translated by Brother Robert in $1226 .{ }^{19}$ Not long after this, the first woman was translated Marie de France in $1270 .{ }^{20}$ Other stories and (anonymous) authors followed. Although the following centuries were quite bleak, there was finally a renewed

16 See also Sørbø, "Discovering an Unknown Austen", 247-48.

17 Just Bing, for instance, is only aware of one Scandinavian translation, the 1920 Swedish "Stolthet og fördom" by C.A. Ringenson. He mentions neither the Norwegian 1871 translation nor those from nineteenth-century Sweden and Denmark, an indication that they were little known (Just Bing, Verdens-litteraturhistorie: grunnlinjer og hovedverker, Oslo, 1929, II, 432).

18 Alf Harbitz, "Preface", in Elizabeth og hennes søstre, Oslo, 1930, 4.

19 Brother Robert is the first known Norwegian translator. For an historical overview, see Magnus Rindal, "Omsetjingsverksemd i norsk mellomalder", in Brobyggere: Oversettelse til norsk fra middelalderen til $i$ dag, eds Magnus Rindal, Erik Egeberg and Tone Formo, Oslo, 1998, 37ff, and Per Qvale, Fra Hieronymus til hypertekst: Oversettelse i teori og praksis, Oslo, 1998, 56. See also English edition of the latter as From St Jerome to Hypertext: Translation in Theory and Practice, London, 1998.

Rindal, “Omsetjingsverksemd i norsk mellomalder”, 39-40. 
interest in translation in the eighteenth century. ${ }^{21}$ All through the nineteenth century Norway saw translations of popular as well as classic authors. Jane Austen's contemporary Walter Scott, for instance, appeared in thirty volumes in $1827-32 .^{22}$ Lord Byron was another translated contemporary of hers. Norway is a small nation, and perhaps for this very reason, has opened up to impulses from the world. ${ }^{23}$

\section{The Early Twentieth Century}

As we have already seen, Jane Austen's name was mostly unknown in Norway before the turn of the century, although she does get a brief mention as early as 1858. Literary histories and school textbooks start including her from the very early years of the century: Just Bing is the one to give the longest and most insightful presentation in his 1905 European literary history. His keen eye and warm enthusiasm, his intimate knowledge of her books, and his reasonable format, are not matched by any other Norwegian literary historian at any time. ${ }^{24}$ (He is only surpassed when the Dane Henning Krabbe writes a ten page presentation of Austen for the pan-Scandinavian World Literary History in 1972. $)^{25}$

In the very early century Austen was also introduced into upper secondary schools for the first time, albeit a brief mention only. She is not among the authors selected for the reading lists. ${ }^{26}$ In the general cultural debate, Sigrid Undset, later Nobel Prize winner of literature for her historical novels, wrote a 1917 article comparing two of Austen's and Ibsen's characters, Emma and Hedda Gabler, both of whom she finds sorely lacking in moral and intellectual qualities. ${ }^{27}$ Interestingly, another famous, Scandinavian woman novelist responded

21 See Erik Egeberg, "Oversettelser mellom middelalderen og 2. Verdskrig”, in Ibid. 53 ff.

22 Qvale, Fra Hieronymus til hypertekst, 56.

23 It serves as an illustration of Even-Zohar's argument referred to in the Introduction above.

24 Just Bing, Europas Litteraturhistorie i det 19de Aarhundrede : Grundlinier og Hovedvcerker, Copenhagen, 1905, 78-79.

25 Henning Krabbe, "Engelsk litteratur", in Romantikken 1800-1830: Verdens litteraturhistorie, eds Edvard Beyer, F.J. Billeskov Jansen, Hakon Stangerup and P.H. Traustedt, Oslo, 1972, VII, 202-12.

26 Austen is mentioned with approval in Otto Anderssen, A Short History of English Literature, Oslo: Det Norske Aktieforlag, 1902, but not included in his textbook. See also Sørbø "The Latecomer: Jane Austen in Norwegian Schools" in Språk og Språkundervisning, 1, $2005,29-36$ and $2,2005,15$.

27 Sigrid Undset, "Hundrede aar: Fra Jane Austen til Henrik Ibsen”, Tidens Tegn, 15 April 1917. 
to Austen's authorship around the same time. Swedish-born Mathilda Malling's 1916 article in a major Norwegian newspaper describes the "six masterpieces" with lucid admiration. Between the lines, she also gives a very dismissive assessment of the only translation she knows, the Swedish Emma she remembers from her father's library, "extremely ... dull ... pale and distorted". Austen can only be properly appreciated in English, Malling finds. ${ }^{28}$

In spite of such important voices, Jane Austen was much less recognized in Norway than George Eliot in these first decades of the century. As Malling also observes, only a few, select readers knew Austen's work. If the rest of the literary world noticed Austen at all, she was a quaint, smaller figure, while Eliot was a larger figure of genius - much translated and well received before and after the turn of the century. However, reception is fickle, and after World War I, none of them had any significant Norwegian contributions for a while.

Then, in 1930, Pride and Prejudice was translated for the first time, as Elizabeth og hennes søstre ("Elizabeth and her sisters"). ${ }^{29}$ The timing suggests that it is a fruit of the early twentieth-century wave of interest in Jane Austen in English academia, which saw several editions of her books before and after the turn of the century, and new books about her. It culminated in the 1923 scholarly edition of The Novels ofJane Austen, with a second edition in 1926 and a third from 1932. The Norwegian translator was evidently aware of Austen's work, and reveals that he has read novels other than the one he is translating, since he recommends Persuasion to his readers (see page 23 above).

The book is handsome, with decorated endpapers and a coloured frontispiece, and illustrated throughout with altogether sixteen drawings by Charles E. Brock from the 1895 Macmillan collected edition. ${ }^{30}$

The translator, Alf Harbitz (1880-1964), was a critic and author of comedies and stories, and a prolific translator of authors like Theodor Dreiser, John Galsworthy, Sinclair Lewis, Jack London, Somerset Maugham, Nancy Mitford, Mark Twain and many others. He is clearly adept at his task, and gives a light and readable version of the novel. He is also one of only two Norwegian translators to provide us with a personal perspective on Jane Austen in his two-page preface.

28 "Uhyre ensformig, nærmest kjedelig ... blege, fortegnede..." (Mathilda Malling, "Sex mesterstykker", Aftenposten, 11 June 1916, 5-6). The mentioned translation must be the 1857-58 anonymous one.

29 Jane Austen, Elizabeth og hennes søstre, Oslo, 1930.

3o The original edition had forty illustrations, so this is a selection. For more information on illustrations, see Laura Carrol and John Wiltshire, "Jane Austen, Illustrated", A Companion to Jane Austen, eds Claudia Johnson and Clara Tuite, Chichester: Wiley-Blackwell, 2012, 62-77 and Cinthia García Soria "Austen Illustrators Charles and Henry Brock" at www.mollands.net/etexts/other/brocks.html. 
It starts with two main impressions: this is a humorous novel, and it is a novel for women: “Of all amusing ladies' novels, Jane Austen's Pride and Prejudice is the most amusing". 31 This translation is explicitly aimed at female readers. Not only does Harbitz try to convince them that "A better book for young girls has never been written ... It is worth more than a whole cupboard full of the usual young girls' books". ${ }^{32}$ In addition, the publisher's adverts at the back places it under "Entertaining books for young girls", among now mostly forgotten and mostly female authors. ${ }^{33}$

It seems, however, that Harbitz insists so much on the book's humour and its "ample supply of love" because his errand is to tempt young readers to try an old, classic author. ${ }^{34}$ For much of his short preface is taken up with a serious and enthusiastic explanation of "a literary masterpiece" that is "still fresh". While more recent novels have been outdated, Jane Austen's "genuineness is ingenious". ${ }^{35}$ Like his contemporary Virginia Woolf, he focuses on Austen's pure art and complete control. ${ }^{36}$

Harbitz also writes a few words about his method of translation, which again only two of the Norwegian translators provide. He wants to "save the tone, freshness, grace" of the "old, English novel" by being "free in letter, but faithful to the spirit". He has attempted "a quicker tempo, a simpler rhythm", to make it "a truly Norwegian book". 37

In spite of the achieved elegance and readability, this preface does not prepare us for the discovery that this version of Pride and Prejudice is at times significantly abbreviated. Harbitz seems to be convinced that a modern translation must also simplify the original, and therefore deletes sentences and passages here and there throughout. This is where translation practice has changed much, and serious modern translators would hardly undertake such editing of a classic author. Unfortunately, he goes even further. To cut an entire chapter

31 "Av alle de morsomme dameromaner er Jane Austens 'Pride and Prejudice' den morsomste" (Alf Harbitz, untitled preface, Elizabeth og hennes søstre, Oslo, 1930, 3).

"En betre ungpikebok er aldri skrevet ... Den er mere verd enn et helt skap med almindelige ungpikebøker" (Ibid., 4).

The only surviving one of the list of translated authors is L.M. Montgomery. There is also a list of girls' books by Norwegian authors, again with one survivor: Barbra Ring.

34 "Den gir dem nok av kjærlighet" (Ibid., 4).

35 "den er et litterært mesterverk" ... "den er fremdeles frisk" ... "denne ekthet er det geniale hos henne" (Ibid., 3).

36 Virginia Woolf, $A$ Room of One's Own, London, 1989, 65.

37 "gjøre den til en virkeleg norsk bok og allikevel å redde tonen, friskheten, ynden. Med stor varsomhet er tempoet satt op, og rytmen er gjort enklere. Fri i bokstaven, men trofast mot ånden..." (Harbitz, preface, 4). 
seems to be increasing the "tempo" rather too much, and to censor people's emotions goes far beyond mere "rhythm", as we shall see in later chapters.

Harbitz is a paradoxical figure in Norwegian Austen reception. On the one hand, he is the only translator before the 1990s to write about Austen's work and literary qualities. Moreover, of all translators between 1930 and the 1970s, he has the best grasp of the English language. Yet, at the same time, he is the only one to censor her story deliberately (the others seem to cut randomly, or only in order to abbreviate). Alf Harbitz admires and censors Jane Austen.

His translation was published by one of Norway's biggest publishing houses (Aschehoug) - the same that sixty odd years later commissioned a whole series of new Austen translations. Whatever its target group and editing, it is a high quality publication. It is one of only three fully illustrated editions of any of Austen's novels in Norwegian. ${ }^{38}$ Unfortunately, very few people can enjoy it, since it is now very rare in libraries ${ }^{39}$ and equally rare on the second-hand market. A copy that belonged to a small public library had been lent seventeen times through the 1930s and then once more in 1948, according to the record at the back. ${ }^{40}$ Harbitz's translation seems to have had a limited readership and distribution. The next translation is easier to find.

\section{Mid-century Translation}

Seventeen years after Elizabeth and her sisters, Pride and Prejudice appeared in Norwegian for the second time, and this time the original title was translated, as Stolthet og fordom. ${ }^{41}$ It is a very different book compared to its predecessor. Quite utilitarian in appearance, it has no illustrations, no preface or other extra material, and the text of the novel is printed on thick, cheap paper bound in beige cardboard with a red spine. It bears witness to the tight economic circumstances of the 1940 .

The dust-jacket provides more glamour, but is also an interesting legacy of its time: the only artwork in this edition, it has often disappeared from secondhand copies. ${ }^{42}$ It is striking in two respects: it depicts a time at least half a

38 The 1990 edition also carries Charles E. Brock's illustrations, while the 1972 edition has drawings by Sandra Archibald. The various editions of the recent Aschehoug series do not include any illustration beyond cover and frontispiece.

There are still copies in Oslo public library (Deichmanske) and The National Library.

40 It used to belong to Trolla Folkeboksamling, Trondheim.

41 Jane Austen, Stolthet og fordom, Oslo, 1947. It was number eight of a series for a book club (Ringen), where the only familiar authors' names are Austen and Oscar Wilde.

The illustrator was Axel Andersen (see page 64). 
century later than Austen's, and a place that looks as if it belongs on the other side of the Atlantic from her England. The motive is a formidable, dark lady in crinoline, huge hat, veil and parasol on the background of a distinctly American mansion with columns and green shutters. It is an echo of the pre-Civil War setting of the Hollywood version of Pride and Prejudice of 1940, and the immensely popular Gone with the Wind of 1939, both filled to the brim with ante-bellum crinolines and hats. ${ }^{43}$ The 1947 dust-jacket is an early example of how the Austen films shape our image of the author.

The dust-jacket also provides a nugget of information about the author that is missing from the book itself. The text on the inside flap (mis)informs us that the book was written when Austen was twenty-one and therefore has the lightness of youth. There is an emphasis on humour and comical characters, but also a reference to her high standing among English novelists. Walter Scott's statement - "What a pity such a gifted creature died so early!" - is quoted. Although it is not difficult to agree with him that Austen's death at forty-one, at the height of her powers, was indeed premature, the Norwegian edition gives the impression that she wrote and died in her twenties. It is a common misunderstanding, also among Norwegian literary historians and critics.

The 1947 translator, Lalli Knutsen, is, like her predecessor Alf Harbitz in 1930, also an author in her own right. Jane Austen has sometimes been translated by author-translators, since her contemporary, the Swiss novelist Isabelle de Montolieu adapted several of Austen's books into French. The question is how, in these cases, the two roles of author and translator influence each other. What artistic, stylistic, thematic or generic luggage does the professional author bring to the translation of another author?

Alfhild Hermana (Lalli) Knutsen (1906-1980) was a journalist, secretary and translator of entertainment literature. Although now forgotten, she wrote a number of novels between the mid-thirties and mid-fifties. ${ }^{44}$ There are many romance stories and entertainment novels by her alone, as well as a number of crime-thrillers co-written with her husband. Their publisher advertised them as "Knutsen Crime Ltd". She published no fiction of her own in 1947, but had published two books the year before and one the year after, so the Jane Austen translation is made in a productive period of crime stories and fiction for young girls.

What is the impact of such an author's own writing and genre on her translation of the texts of other writers? To what extent will the author-translator

43 See Chapter Three of Marie N. Sørbø, Irony and Idyll:Jane Austen's Pride and Prejudice and Mansfield Park on Screen, Amsterdam and New York, 2014.

44 Her twenty-one titles fill a long column in Norsk kvinnelitteraturhistorie ("Norwegian Women's Literary History”), eds Irene Engelstad, et al., Oslo: Pax, 1990, III, 265. 
recreate the translated author in her own image? Lalli Knutsen's generic location as author and translator is significant in two ways. The choice of translator reveals the publisher's view of who Jane Austen was. Although Knutsen's translations range from Ouida to Zola, there are more of the former type than the latter. Assigning her the task of translating Jane Austen indicates that Austen herself was seen as belonging in the entertainment genre. Moreover, the publisher in question, Nasjonalforlaget, was also Knutsen's own publisher, where she appears to have worked as consultant and secretary.

Secondly, Knutsen's own genre must have influenced her style of translation. This is confirmed by a study of her choices, as we shall see in the following chapters. The more fundamental observation is that there is a striking shift in tone compared to the source novel. This is not least evident in Knutsen's tendency to use stronger language than Austen, her propensity for modern idiom, and the loss of original irony.

In addition, Knutsen has a weaker understanding of the English language than the first two Norwegian translators. Mistakes abound, as do attempted amendments to Austen's text. She does, however, give us a fuller version of Pride and Prejudice than Harbitz did, not indulging quite as much in deletions.

There are a handful of surviving copies in academic libraries, though Knutsen's translation seems to have disappeared from public libraries, where it has been replaced by its two successors. Rather surprisingly, Knutsen's version of the novel was the one chosen for a textbook extract for upper secondary schools forty years later. ${ }^{45}$ The publisher, Aschehoug did not prefer their own, better, translation from 1930, nor the then latest one from circa 1972.

Knutsen's version is also the one used for a 1972 audiobook edition made specifically for the blind. ${ }^{46}$ Again, the weaker translation is preferred to the better, a clear indication that by this time Harbitz's version was long forgotten.

\section{The $1970 \mathrm{~s}$}

The early 1970s saw the third Norwegian Pride and Prejudice, a translation that dominated the Norwegian market for three decades, and is still found in many libraries, not least due to several new editions and reissues. ${ }^{47}$

45 Per Buvik and Geir Mork, Jeg fant, jeg fant! Lesebok I. Fra norrøn tid til århundreskiftet, Oslo: Aschehoug, 1988.

46 Jane Austen, Stolthet og fordom: til norsk ved Lalli Knutsen, Oslo: Norsk Lyd- og Blindeskriftsbibliotek, 1972.

47 Jane Austen, Stolthet og fordom, Oslo, undated circa 1972. David Gilson gives the year as 1973 (Gilson, A Bibliography of Jane Austen, 198). 
Three different book-clubs have offered it to their members in 1972, 1990 and 1997, in classic, hardback editions. ${ }^{48}$ Other editions catered for other tastes, to wit a 1991 paperback whose main title was Elizabeth, and only in smaller print: Stolthet og fordom. It is designed to appeal exclusively to female readers, with its cover-painting of a Victorian girl, adorned with flowers and a red heart, and the promise of "the best love stories". ${ }^{49}$ This edition was reissued three more times over the following five years, although gradually without "Elisabeth" in the title. The 1972 translation re-appeared as late as 2009, in the form of an audiobook set of CDS, as well as in a 2000 edition of the novel with a cover photo from the 1995 ВвС series.

The translators seem to have been a married couple: Eivind and Elisabeth Hauge. They are the most unknown of all the twentieth-century Austen translators. Library records, however, reveal that Eivind Hauge (1915-1970) was a translator of around fifty titles, most of them entertainment fiction by authors like Edward S. Ellis, Jules Verne, Robert Louis Stevenson, James Fennimore Cooper, H. Rider Haggard, Ray Bradbury, and Agatha Christie, plus a host of now forgotten names. ${ }^{50}$ When he translated Dickens' Oliver Twist, it was probably seen to belong in the same genre. These translations were done between 1941 and 1960. In addition, he translated plays for theatre and radio, some of which date to $1960-70$.

Like Harbitz and Knutsen before him, Eivind Hauge was also an author: he published a collection of short stories in 1941 and poems in 1960 (the latter included four translations from English). Elisabeth Hauge translated at least ten titles, particularly Swedish children's books, and also a couple of English titles between 1944 and 1952. Both spouses thus seem to have been most active in the Forties and early Fifties.

These dates illustrate a main conundrum relating to this translation. There is no trace of any publication of it before 1972, and yet, their translation bears all the marks of the mid-century language style, with not even a hint of the 1970s. Reading it as the 1970s version of Austen therefore becomes increasingly

48 Austen found herself among the "Famous authors" series of "The Collector's Book Club" (Samlerens bokklubb), she was selected for book of the month in "The Norwegian Book Club" (Den norske bokklubben), and was among the chosen in "Cappelen's book club's selected".

49 The painting is "April Love" by Arthur Hughes (1856), see illustration page 185 (Jane Austen, Elizabeth: Stolthet og fordom, Oslo, 1991).

5o The year of his death is not listed in library records, but he is probably the author listed in a catalogue of regional authors (http://www.haugesund.folkebibl.no/haugesundsforfattere.htm). Since he died in 1970, he may not have had much of a hand in the final completion of the Austen translation, which may imply that his wife took it over after his death (see below). 
puzzling. It has a flavour of the 1950s, although on the market only since 1972, and most read in the 199os.

Part of the solution to the riddle is that many of the Hauge translations seem to have been reissued decades later, whether as popular bestsellers, "great classics" for the young, or children's books. Right before their Pride and Prejudice was published in Samlerens bokklubb (the collector's book club), Eivind Hauge's Oliver Twist appeared in the same series (1969). However, while this is a re-editing of a 1949 translation, there is no documented earlier edition of their Austen translation.

This double context of the translation in effect modifies the picture: although there are around two decades between each of the three first translations of Pride and Prejudice (1930-1947-1972), all these four translators seem to have been active around 1950. They were more or less contemporaries. Harbitz was admittedly a generation older than the others, but in age there were only ten years between Knutsen and Eivind Hauge. In effect, all three translations can be said to be broadly speaking mid-twentieth century ones. Naturally, this has bearing on the stylistic choices, as we shall see.

The Hauges' translation is fuller, with fewer cuts than the earlier versions, but it is also weaker, not least due to their tendency to paraphrase the original story. It is, moreover, oddly uneven. The first thirty-five (of sixty-one) chapters are poorly translated, with mistakes and rewritings, only relieved by glimpses of good dialogue. Then suddenly Chapter 36 is markedly better than earlier. It follows the original quite closely, echoes Austen's tone, and has only a couple of lapses. This is kept up for a few chapters, until we again come up against rewritings and simplifications, and a naïve tone of narration. From there, the two language levels seem to alternate, with a few chapters each. Evidently, the couple divided the novel between themselves, rather than cooperating on the whole manuscript, and one of them was a weaker translator than the other. Unfortunately, although also Chapters $47,51,57,58$ are well translated, the weaker translator dominates the book. In some places, there is a sudden drop in quality within the same chapter, for instance when the last paragraph of their Chapter 49 (III, 7) is much more weakly translated than the rest of the chapter, and heavily abbreviated. ${ }^{51}$

\section{Serialization}

Very soon after the circa 1972 translation, yet another Norwegian version of Pride and Prejudice appeared, as a serial in the magazine Familien (the family) 
between 5 March and 8 October $1974{ }^{52}$ It has three features in common with the 1871 serialization of Persuasion. First that the translator is not named. Secondly, in spite of a potentially large readership at the time, it was soon forgotten and has not been registered in library catalogues or other inventories. Thirdly, the original title is changed, in this case Pride and Prejudice sports the title Omvei til lykken ("detour towards happiness").

The anonymous translator remains a mystery. Journalist Lise Vislie Jor (born 1929) edited the serial and wrote an accompanying article about Jane Austen for the first instalment. ${ }^{53}$ As she remembers the process now, more than forty years later, she did not translate the novel from English, but rather adapted an already existing "old edition". The text is, however, different from all three previous Norwegian translations, as we shall see. It may have been based on an earlier serial that is not registered in library catalogues. ${ }^{54}$

The readers of the Familien magazine are introduced to Jane Austen by means of her portrait (the Victorian, etched version) and a text-box presenting her as a master, a classic author comparable to Shakespeare, with an indication of a connection to feminist concerns. Her famous "little bit ... of ivory" declaration is quoted in full, and serves as a title for Lise Vislie Jor's article. ${ }^{55}$ Jor provides a quite well-informed and sensible situation of Jane Austen among predecessors (all male), and as acclaimed by later critics and authors (all male). She is said to have found her own way of writing that was quite different from the host of sentimental novels for female readers. Her characters are her particular strength, representing still recognizable human frailties, described with irony and humour.

$5^{2} \quad$ Jane Austen, Omvei til lykken, Oslo, 1974.

53 Lise Jor, "Et lite stykke elfenben", Familien, 5 March 1974, 14-15 and 71-72. Vislie Jor was active as a writer in the 1970s and 8os, especially on cultural and church life, and did some translations of children's literature.

The source could conceivably also have been other Scandinavian translations, but the two Swedish versions of 1920 and 1946 have no additions or omissions, as claimed by Git Claesson Pipping and Eleanor Wikborg, "Jane Austen's Reception in Sweden: Irony as Criticism and Literary Value", The Reception ofJane Austen in Europe, eds Anthony Mandal and Brian Southam, London, 2014, 158. Likewise, the Danish 1952 translation is described as being close to the novel: Peter Mortensen, “Unconditional Surrender'? Jane Austen Reception in Denmark", Ibid., 126. The earlier 1928 Danish translation by Ebba Brusendorff also seems much more complete than the 1974 version (Jane Austen, Stolthed og fordom, Copenhagen, 1928-30).

55 "the little bit (two inches wide) of ivory on which I work with so fine a brush, as produces little effect after much labour" (Jane Austen's Letters, ed. Deirdre Le Faye, Oxford, and New York, 1995, 323). 
Although written for the broad, general readership of a fortnightly magazine, the article appeals to a serious, 1970 s feminist interest in Austen, rather than to a popular one, especially when compared to the 1996 version of the same translation. For, twenty-two years after the first serial, the same magazine again presented a version of Pride and Prejudice, but this time as a sixteenpage insert in one issue, rather than a running serial. The obviously shortened novel starts with a summary of the twelve first chapters, so only enters the action when Mr Bennet announces Mr Collins' arrival in the beginning of I, 13 . More brief summaries follow, alternating with excerpts from the 1974 translation. The editing was done by another journalist, Inger Helene Arpas, who also incorporated an extract from Jor's article. ${ }^{56}$

This publication was clearly made in connection with the airing of the ввС 1995 Pride and Prejudice on Norwegian television. Photos from the serial fill seven pages, supplemented with two portraits of Jane Austen. The story is introduced as "the current television serial", and is "a spring present to our readers" who saw the first episode "last Thursday". The reissue of this edited version of the 1974 translation is thus a token of the immense Austen interest caused by the screen adaptations of the 199os.

\section{The 1990s Jane Austen Renaissance}

The new wave of enthusiasm for Austen's work since the mid-Nineties is mostly attributed to the unparalleled success of the 1995 в вс Pride and Prejudice miniseries, starring Colin Firth and Jennifer Ehle. It was preceded by Persuasion (April 1995) and immediately followed by three more Austen productions for cinema and television in 1996: one of Sense and Sensibility and two of Emma. Three years later, there was a new Mansfield Park, while Northanger Abbey was left out of this 1990s Austen revival on screen. ${ }^{57}$

At first glance, the appearance of a series of Norwegian translations at exactly this time seems to be another side-effect of the adaptations. The order is slightly different: Emma (1996), ${ }^{58}$ Fornuft og folelse (Sense and Sensibility, 1997), ${ }^{59}$ Overtalelse (Persuasion, 1998), ${ }^{60}$ Mansfield Park (2000) ${ }^{61}$ and Stolthet

\footnotetext{
56 Jane Austen, Stolthet og fordom, ed. Inger Helene Arpas, Familien, 1996, 9.

57 For a discussion of the adaptations, see Sørbø, Irony and Idyll, 2014.

58 Jane Austen, Emma, Oslo, 1996.

59 Jane Austen, Fornuft og følelse, Oslo, 1997.

6o Jane Austen, Overtalelse, Oslo, 1998.

61 Jane Austen, Mansfield Park, Oslo, 2000.
} 
og fordom (Pride and Prejudice, 2003). ${ }^{62}$ Again Northanger Abbey was left out, and has never had a Norwegian translation.

However, as the translator informs us in her postscript, she was commissioned to do the translations already in the spring of 1994, on returning from a visit to Jane Austen's grave in Winchester. ${ }^{63}$ The publishing house, Aschehoug, had perhaps caught the Austen buzz in the air prior to the television releases. At any rate, the coinciding film wave and book series meant a renewed interest in Jane Austen's authorship in Norway. ${ }^{64}$

The five translations were all done by the same woman, Merete Alfsen (born 1950). She has translated many novels since 1986, not least by contemporary women authors like Alice Hoffman, Amy Tan, Margaret Atwood, Ali Smith, A.S. Byatt, but also several of Virginia Woolf's books. Four of her translations have won prestigious prizes (for instance her translation of Woolf's Orlando).

Of Alfsen's five Austen translations, her version of Pride and Prejudice is chosen for the present study. The other four titles are not included, as the aim is to compare the seven main Austen translators and their choices.

Stolthet og fordom (2003) stands out as the only complete Norwegian translation of this novel. Some of the earlier translators did not aim for completeness, indeed Harbitz declares his intention to treat the text with some liberty. Others seemed to miss the goal, or not be aware of it. Merete Alfsen is the first translator since the anonymous one of 1871 to achieve a full translation of all of Austen's original text, down to the smallest details of linguistic peculiarities or quaint expressions.

Her five translations of Austen were originally part of a series called "De store romancer" ("the great novels"), but were soon reissued in other series (such as "Aschehoug Tradisjon") and book club editions. This ensured them a certain readership as well as a clearly defined status as classic literature. They are often heavy hardback volumes, as befitting a canonized author. Although they generally have a short shelf life in the bookshops, new editions appear - a beautiful, clothbound 2016 gift book edition for instance. Alfsen's translations now also dominate the library collections of Austen, so it is to be hoped that after the original novels they will be the preferred choice for all Austen readers.

Norwegian readers will have difficulty judging the book by its cover. Readers who prefer leather-bound volumes, and pick up the most beautiful of them all, a dark blue with rich gold ornaments, and lovely blue and gold endpapers, will

\footnotetext{
62 Jane Austen, Stolthet og fordom, Oslo, 2003.

63 Merete Alfsen, "Oversetterens etterord", in Stolthet og fordom, Oslo, 2003, 359.

64 See Marie Nedregotten Sørbø, "Jane Austen and Norway: Sharing the Long Road to Recognition", in The Reception of Jane Austen in Europe, eds Mandal and Southam, 132-52.
} 
get the poorest translation (by the Hauges) - and they will also get an idiosyncratic portrait of Jane Austen, by Sandra Archibald. ${ }^{65}$

If they pick up the second most beautiful, in red leather with gold, they get the 1990 book-club edition with Charles E. Brock's illustrations throughout, but the Hauges' translation. ${ }^{66}$ Readers who prefer books with film stars on the cover, could go for the 2000 edition with (half of) Jennifer Ehle's face in extreme close-up, ${ }^{67}$ or for Keira Knightley's profile on the dust-jacket of the 2006 edition. ${ }^{68}$ The first group of readers will get the Hauges' translation, the latter group will get Alfsen's.

Although all translations are reasonably light and readable, translators choose contrasting strategies for rendering Jane Austen's text. The 1871 translator was erudite and expansive, while the 1930 one was an admirer and a censor. In 1947 the translator chose the style of a crime writer, while the 1970 translator couple were paraphrasers. The mysterious 1974 translator shortens and simplifies, and the 2003 one is a conscientious transmitter. These strategies may all, however, have inherent problems, even the strategy of faithful transmission. The following chapters will focus on particularly striking issues and give examples to illustrate the dilemmas and challenges of literary translation.

65 This seems to stem from a 1968 reprint of the $1953-54$ edition of the novel, published by Heron Books, which also has a very similar cover to the Norwegian one. This edition was probably that used by the translators. However, in contrast to the translation, the Heron Book edition seems to be complete.

66 Austen, Stolthet og fordom, 1990.

67 Jane Austen, Stolthet og fordom, Oslo, 2000.

68 Jane Austen, Stolthet og fordom, Oslo, 2006. 


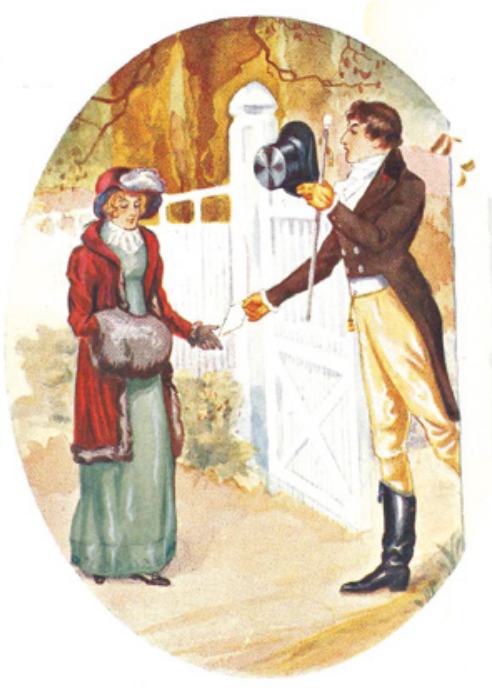

Jane Austen

Elizabeth og hennes søstre

Oversatt av

Alf Harbitz

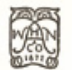

Oslo 1930

Forlagt av H. Aschehoug \& Co.

(W. Nygaard)

FIGURE 3 The 1930 translation of Pride and Prejudice, with the title Elizabeth and Her Sisters, is a beautiful book, sporting some of Charles E. Brock's illustrations. 